\title{
A revolta da casa dos ídolos de Pepetela
}

Por Tatiane Mattos ${ }^{1}$

Reconhecido por sua vasta obra romanesca que costuma retratar a realidade angolana, Artur Carlos Maurício Pestana dos Santos, Pepetela, escreveu - em 1978 e publicou em 1979 - a peça teatral A revolta da casa dos ídolos. Ao contar uma história passada no Reino do Kongo de 1514, a narrativa revela, frente a Angola recémindependente do ano de sua publicação, as explorações sofridas pelo povo daquele reinado perante o avanço das ambições dos portugueses e da aristocracia local; e o despertar de uma jovem consciência que questionará o que por hábito, costume e opressão se sustentou até aquele momento no Reino.

O Reino do Kongo abrangia a esta época do século XVI, na qual se passa a ação dramatúrgica, o território que corresponde hoje a parte da África Central (noroeste de Angola, Cabinda, Gabão, República Democrática do Congo e República Popular do Congo). O mito que dá origem a obra de Pepetela diz respeito ao início das atividades portuguesas neste espaço, e ao estabelecimento de um acordo entre os portugueses e os manis (representantes da aristocracia do Reino), que resultaria na cristianização dos reis manicongos, como eram conhecidos. O primeiro rei manicongo a se converter a religião católica foi o Rei Nzinga-a-Nkuwu, que, batizado, passa a se chamar D. João I. Seu filho, Mvemba-a-Nzinga, converte-se em D. Afonso e, com a morte do pai e o apoio dos portugueses, assume o reinado, mesmo a contragosto dos outros manis. A peça $A$ revolta da casa dos ídolos é inspirada neste contexto histórico.

No primeiro ato da peça, deparamo-nos com uma narrativa dupla que apresenta por um lado o tempo atual, ilustrado por uma conversa entre Nimi, o ferreiro, e Nanga, seu sobrinho; por outro, os acontecimentos ocorridos até então, demarcados pela instauração de um novo universo: o regime colonial. Com a intensiva investida portuguesa no território, o reino do Kongo e a maneira de definir seu governo passam por significativas transformações. Após a morte do rei, seu filho, D. Afonso, assume o

${ }_{1}$ Mestranda do Programa de Estudos Comparados de Literaturas de Língua Portuguesa da Universidade de São Paulo. 
trono que deveria ser de Mpanzu-a-Nzinga, o escolhido pelo Conselho dos Manis. Mpanzu-a-Nzinga morre numa batalha, na última tentativa de assumir o reinado, e Mani-Vunda, responsável pelo Conselho, passa a ser, junto a seus filhos, o faxineiro da Igreja.

É nesta inversão da ordem antiga, numa impositiva troca dos valores kongolenses por valores portugueses, que o leitor se dá conta da dificuldade de se manter um reino tal qual o era após a chegada da colonização, com seu poder bélico, que amputa antigos modelos sociais. O reino nas mãos de D. Afonso fica entregue aos exploradores portugueses, cuja ambição é insaciável.

No entanto, é esta exacerbada ambição a responsável por uma tomada de consciência de Nanga, o aprendiz de ferreiro. Nanga, ao longo do segundo ato, busca desesperadamente compreender qual é o medo dos portugueses e o que está por trás da "caça" aos amuletos africanos (chamados por estes de ídolos). Não demora muito para, em companhia de Masala, um Mani vendido como escravo após discordar dos métodos de exploração aplicado por seu tio, Mani Soyo, descobrir que o temor português era a revolta daquele povoado unido.

Essa união, se era temida pelos portugueses, também não era desejada pelos manis, que representam a aristocracia local. A sobrevivência destes se dava através da cobrança de tributos do trabalho da plebe do Reino do Kongo. Com a chegada dos portugueses, os tributos aumentaram, e a escravatura-mercantil se tornou a principal fonte de lucro.

Ao descobrir que o interesse português era mascarar a escravatura, Nanga parte para o ataque. Masala e ele iniciam, então, um processo de conscientização da população. Mas é a queimada da casa onde eram guardados os amuletos que gera a grande insatisfação. Nervosos com o ato que desafiava as suas tradições, eles se articulam para tirar o rei D. Afonso do trono. A consciência da situação em que se encontram ganha espaço. Há uma movimentação voltada para a luta, que culmina no homicídio de Lopes, o comerciante português. A única morte efetuada pelo povo é, portanto, a morte do representante da escravatura.

Mani-Vunda e Muxuebata contém a rebelião, na tentativa de estabelecerem-se no poder. Assassinam Nanga e sequestram Masala, devolvendo-o para seu tio ManiSoyo. Aproveitando-se da fragilidade da insurreição popular sem os seus "líderes", os portugueses atacam e vencem com facilidade. Os manis voltam a depender do governo 
agraciado pelos portugueses, e o povo continuará a ser, por tempo indeterminado, explorado por aqueles que se encontram acima de si na pirâmide social.

A ação dramática apresenta, portanto, duas facetas da opressão às quais o povo está submetido. A primeira, mais antiga, realizada pelos manis, os aristocratas. A segunda, recente, feita pelo colonizador, que a si submete não apenas o povo, como também os próprios manis. Uma forma de oprimir está intrinsecamente ligada à outra, e ambas estão relacionadas às ambições pelo poder.

Embora as imposições portuguesas sejam mais facilmente identificadas por Nanga, e, consequentemente, pelo leitor, é na imposição aristocrata que parece residir a revolta presente no título. Crentes em sua religião e dotados da certeza que não há força alguma além da tradição que seguem, o povo kongolense depende desta consciência despertada nos jovens para conseguir, com dificuldade e por curto espaço de tempo, romper com certos costumes que limitam as possibilidades de mudança.

Com medo de desrespeitarem os espíritos, os antigos se submetem, sem questionar, aos manis, mesmo que estes repetidas vezes tenham demonstrado preocupação apenas com o bem estar próprio. Necessário se faz então que um jovem mani questione tal poder. Ao se revoltar, Masala explicita sua má vontade para com aquela ordem estabelecida. E incita em Nanga - o jovem que pertence à plebe e que se preocupa com as condições de vida de seus iguais - a mesma revolta, imputando a este questionamentos novos com relação a costumes antigos. Juntos eles iniciam a conscientização contra a opressão e o movimento de luta para se libertarem dos tributos e da escravatura.

A morte e o sequestro, no entanto, embora tragam em si a desesperança, não podam por completo as possibilidades de transformação. O povo volta a se submeter aos manis, e estes, por sua vez, voltam a se submeter aos portugueses. Neste universo fragmentado, sem que haja a consciência da força popular, imperam as vontades portuguesas representadas pelo padre, o exército e os comerciantes. Toda tentativa de mudança é paralisada. Ainda assim, o texto evidencia que uma consciência desperta não desaparece facilmente. Na declaração de tio Nimi, Nanga - não o indivíduo, mas sua consciência - está vivo. “Quem poderia tirar a vida à própria vida?” (PEPETELA, 1980, p. 142). A morte não determina o fim. A última cena é de Kuntuala, o futuro. E no futuro, a esperança reside.

Com este texto dramatúrgico de caráter épico, Pepetela se coloca mais uma vez na posição de autor que evoca em seu leitor, através do desenvolvimento narrativo, 
questionamentos a uma sociedade em transformação. Na tensão estabelecida, é o próprio leitor que pode ser tomado pela revolta.

Destacando que o texto foi escrito em 1978, três anos após a independência de Angola, e tendo como norte dois aspectos que parecem imperar na peça - a usurpação daqueles que estão ou estiveram no poder e o despertar de uma nova consciência podemos arriscar dizer que temos em mãos um manifesto contra aquilo que já foi, a colonização, mas também um alerta contra as possíveis amarras da nova sociedade que se forma.

PEPETELA. A revolta da casa dos ídolos. Lisboa: Edições 70, 1980. 